\title{
Development of Project-based Blended Learning (PjB2L) Model To Increase Pre-Service Primary Teacher Creativity
}

\author{
Wahyudi ${ }^{1}$, Adi Winanto ${ }^{2}$ \\ ${ }^{1}$ Faculty of Teacher Training and Education, Universitas Kristen Satya Wacana, Indonesia \\ Email: yudhi@ staff.uksw.edu \\ ${ }^{2}$ Faculty of Teacher Training and Education, Universitas Kristen Satya Wacana, Indonesia \\ Email: adiwin@staff.uksw.edu
}

(Received: March-2018; Reviewed: April-2018; Accepted: May-2018; Published: August-2018)

(C2018 -EST Graduate Program Universitas Negeri Makassar. This is an article with open access under license CC BY-NC-4.0 (https://creativecommons.org/licenses/by-nc/4.0/ ).

\begin{abstract}
One of the aims of Indonesian education is to develop the potential of learners to become creative human beings. It takes a creative teacher to meet this need. Not just teaching, but teachers who are able to teach with innovative models, strategies and methods provide an opportunity for students to be skilled from creative products including in the field of mathematics in elementary school (SD). The aim of this research is to develop model to grow pre-service primary teacher students' creativity in designing the lesson plan. The method used in this research was R\&D with ASSURE development model. Product validation was done through an expert's assessment by using the expert's validation sheet. Product effectiveness was seen by implementing limited development testing to a particular class with a one group pretest-posttest design and the result was analyzed by using a Paired-Samples T-Test. The result of this research was a project-based e learning model to increase the creativity of pre-service primary teacher college students in designing a lesson plan. The validity of the learning model was proven by the result of the expert assessment in learning (face-to-face and online), material and instructional media. This model is also effectively usable in instructions to produce creative lesson plans for teaching Elementar School Mathematics as it is shown by the difference in the average pretest and posttest scores with sig. (2-tailed) 0,000.
\end{abstract}

Keywords: Learning Model; Project- Based Blended Learning; Students' Creativity; Lesson Plan.

\section{INTRODUCTION}

The demand of the present age cannot only be satisfied by cognitive abilities, but also by skills and good attitudes to create a balance among the cognitive, psychomotor, and affective competencies. Such a demand has been indicated in the 21st century, expecting humans to possess three kinds of skills, i.e., 1) life and career skills, 2) learning and innovation skills, and 3) information, media and technology skills. These three skills will produce humans who have high creativity, and ability to enable them to compete and even give contribution to the prosperity of the community. This situation can be realized when one is well equipped with creative learning activities. Therefore, there is a need for an ability to create creative learning in to provide an opportunity to the learners to develop his or her creativity in making something. Creativity is an integration of someone (Khairullina, 2016). Widiana and Jampel (2016: 246) said that learners interest and happy with the creative teaching-learning process, such as implemented multiple intelligences use mind mapping. Widiana and 
Jampel (2016: 252) added, teaching-learning process would implement multiple intelligence so that increasing learners' creativity.

Also, technology has developed at an extraordinary rate. In the educational sector, for example, computer and internet have been used extensively as learning media. Those have made it easier to do assignments, to save time, and even to enrich information as learning sources. Computer and internet have made students quicker in receiving and getting information on learning materials. Using technology in teaching-learning process can improve students' accomplishment in understanding new knowledge and broader the implementation of that knowledge in future professional activities (Krinistsyna, 2016, p. 11709). The technology uses in learning by using visual media to increase students' attention, participation, and interaction. Besides that, technology in learning because of the limited of students' participation, time management, motivation, and finding learners' need (Liu, 2016, p. 87).

A teacher should respond such a phenomenon immediately, so that the $21^{\text {st }}$ century demands as well as technological advances can be utilized properly to support teaching-learning processes. The teacher has to be able to collaborate between planning ability, pedagogic teaching, and material mastery with the technology to produce creative learning which may cater student's needs for the present era demands. Today students have used laptops, Ipads, tablets, and cellphones in their campus activities so that learning should be made in such a way that it can provide facility to access learning needs with the gadgets more effectively in an enjoyable learning situation and can be done in any place and time. E-learning offers learning which is flexible in the sense that elearning can be accessed anywhere and anytime as long as within reach of the internet (Hasyim \& Haling, 2017)

To wrap up such a learning model, a teacher needs a special expertise. It will not only provide content materials or a pedagogical planning ability, but it also needs an ability to combine both. One will also need a special skill in utilizing technology in learning. By combining the three skills, learning will become more interesting, efficient, and meaningful. Like as what Giacomini $(2015$, p. 37) done in her class, where she used technology in her English language class, she uses "Storybird". By utilizing internet, she created two storybird classes and then she wrote her story, asked her students to join in the storybird account, and started to write their own story and personal story in English. By storybird, Giacomini created an effort to maximized learning opportunities through meaningful learner involvement, where the students motivated to write their story in English, but also controlled their learning experience (Giacomini, 2015, p. 37).

Besides being interesting, efficient, and meaningful, learning should provide an opportunity either for the students to produce a particular work, which comes from the students' creativity individually or in groups. Such creativity must be motivated and developed by the teacher in a way that learning will not only be a matter of completing the teaching materials but also of getting a skill in the form of creativity, leading to producing a written work which is publishable in a scientific journal. This way, it may encourage students in not only doing assignments and getting a score, but also learning to produce a work.

All this can be realized if the teacher performs a project-based learning. The process includes a face-to-face classroom session and or using an online procedure, so the students can learn at any time and place with the materials and activities prepared beforehand. Beside that, the teacher may present learning sources online which may enrich the planned materials along with creative online examples. With this type of learning model, it is commonly expected that education produce special type of alumni who serve as a creative minority, one that the university intends to achieve as its mission.

According to Morisson, Ross, and Kemp (Winataputra, 2001), a learning model will help program planners or support learning activities in understanding theoretical framework in a better way as well as applying the theories to produce a more effective and efficient learning activity. A learning model plays a role as a conceptual tool, management, communication for analysis, planning, creating, and evaluating learning outcomes. A learning model is a conceptual framework that explains a systematic procedure in organizing learning experiences to achieve particular learning objectives.

To perform a model, Joyce, Weil \& Calhoum (2015) identified a model that consists of five aspects. The firt aspect is a syntax or an 
order or stages of learning activities that are put into phases illustrating how the model works out in its practicality, for example, how to begin a lesson, and how to facilitate learners in using learning resources. Second is a social system that explains about forms of teacher-student cooperations in learning or roles of the teacher and the students in their relationship, and types of rules to be implemented. Third is a reactional principle that shows the teacher how to appreciate or evaluate students and how to respond to the students' work. Forth is a support system which illustrates conditions needed to dupport the implementation of the learning model, including tools and infra-structures to meet the required conditions for the successful implementation of the learning model, includinh means and infra-structures, readiness to teach, and student readiness to learn. Fifth, is a direct and indirect instructional impact, i.e., the learning outcome, which is achieved by bringing the students to the expected objectives and other learning results as a product of the direct learning process that is experienced by the students.

One of the models, which can be developed, is the creative learning model. The creative learning model is one that stimulates learners to develop their ideas by utilizing existing learning resources. The creative learning has done in four learning phases, i.e., (1) preparation; (2) incubation; (3) illumination, and (4) verification (Wallas, 1926). It also can be done by way of project-based learning in a blended learning mode.

The project-based learning is one that focuses on teaching-learning activities to make a particular product or work. Project-based Learning is a systematic teaching method that engages students in learning important knowledge and the 21st century skills through an extended, student-influenced inquiry process structured around complex, authentic questions and carefully designed products and learning tasks." (Vastenhouw, 1982). Project-based learning is a method that place the students as a central learning process, as a central and following the lesson plan, and in the PBL class teacher leads the students to the learning that they want or following the project's goal (Koparan \& Guven, 2014, p. 147).

The word project comes from Latin "proyectum", which means an intention, an objective, a plan, a budget (Vastenhouw, 1982). Project-based learning brings students to make a plan and to executing the planned project while the teacher serves as a facilitator who evaluates the completed project by of negotiated criteria as a result of class discussion. Learners will individually complete their product without teacher's help. They will even evaluate the work of their group members.

The blended learning requires the provision of an opportunity and widely accessible learning resources. Etymologically, the term blended learning consists of two words, "blended" and "learning". The word "blend" means to mix for making the quality better (Collins Dictionary) and "learning" has a general meaning of "to study". Thus, "blended learning" means a learning pattern that has the sense of mixing or combining one pattern with another pattern. Charles, Hartman \& Moskal (2004) says, "Blended learning refers to courses that combine face-to-face classroom instruction with online learning and reduced classroom contact hours (reduced seat time). The latter point is an important distinction because it is certainly possible to enhance regular face-toface courses with online resources without displacing classroom contact hours." Blended learning is called hybrid learning, that combine the characteristic of traditional school with the benefit of online learning for personal delivery, different instruction each learners group (Powell et al, 2015: 5). Blended learning is an innovative concept include positive superiority from traditional learning as well as learning supported ICT (Lalima \& Dangwal, 2017: 129). There are five keys to the implementation of blended learning according to Jared M. Carmen, i.e., life events, self-paced learning, collaboration, assessment, performance, support materials.

\section{METHOD}

Developmental Procedure and Its Implementation. The design model for learning system which is developed by ASSURE model comprises six stages, i.e., 1) analyze learners, 2) state objectives, 3) select strategy, technology, media, and materials, 4) utilize media and materials, 5) require learner participation, 6) evaluate and revise (Smaldino, Russel, Heinich, \& Molenda, 2005).

The following diagram shows the model more clearly. 


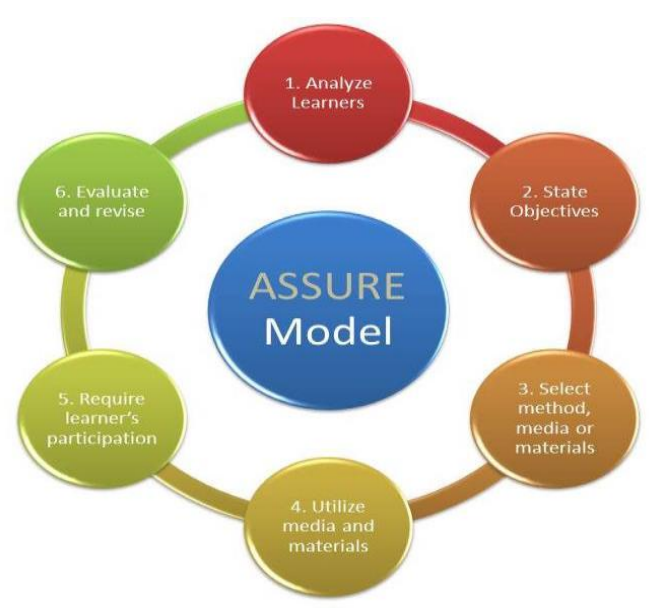

Figure: 1

The ASSURE Developmental Model

The above diagram shows detailed steps in developing the ASSURE model design as the following; Analyze Learners is the first step to be done is the identification of characteristics of learners engaged in a learning activity. The population in this research is the 2013 PGSD students. The result of the analysis will be used to see the students' ability in using computer and internet facility, and to know their initial knowledge in the Elementary School Mathematics Learning Subject 1 to decide what method and learning process are appropriate and efficient. State objective is the second step is to decide the learning objective based on the result of the analysis of students' characteristics. This result along with their basic competency and indicators as stated in the curriculum is based on the principle of project-based learning and blended learning. It is expected in this principle that the relationship between learning materials, technology, and pedagogy has the power and attraction to motivate students' creative learning. The third step in developmental method is Select method, media, and material, which is to decide method, media, and learning which will be used in both the face-to-face and the online instructions. This is important because the three components play the role of helping students to achieve learning objectives that have been stated beforehand. Its decision depends on the student characteristics, the learning objectives, and learning principles of the project-based learning that are prepared for both face-to-face instruction and online in a flexible learning mode. The forth step is utilize media and materils, after selecting the method, media, and teaching materials, the next step is using the three components in a learning activity. Before applying them in a learning process, an expert validation needs to be done first to see the quality and appropriateness of the media and teaching materials and the lesson plan. After the expert validation, the next step is performing a limited trial test in a small group (5-10 students). Require learner participant, is engaging students in an instruction. The students participate in the face-to-face learning and online instruction based on the plan already prepared. The learning process refers to the learning principles according to the projectbased learning, so that the face-to-face and the online instructions help the students with their creative work taking the form of a creative learning plan for the Elementary School. It will in turn be used as a scientific work to serve as an idea for the Student Creativity Program. The last step is evaluate and revise, after the lesson plan is done and tried out, the next step is evaluation. The evaluation is performed to collect data related to the strengths and weaknesses of the learning model used. Its product is a creative learning activity plan using the project-based learning in a blended learning class consisting of teacher's manual; student's learning manual, and other learning tools, such as a lesson plan, student's work sheets, teacher's activity sheets, and student's response sheets. The result of the evaluation process can be used as an input for the improvement of the learning program.

Data Collection Technique and Instruments. The data collection technique employed in this research is an expert's test, a questionaire, and a test. The expert's test is used to see the appropriateness of the product. The questionaire is used to know the student's responses to learning, and the test is administered to see the impact of the learning involved. The instruments used in this research is the expert's validation sheets, a closed questionnaire, an open questionnaire, and test material.

Data Analysis Technique. The data was analyzed through validation and a try-out by calculating scores obtained to judge the quality of the learning model to be developed. The collected data in this research is qualitative data. The data in scores of 1-5 (score 1 for very poor, score 2 for poor, score 3 for fair, score 4 for good, and score 5 for very good) taken from the result of the assessment of the expert and the students in relation to the learning being applied, 
the strengths, and the weaknesses of the learning process.

The result of the pretest and the posttests was analyzed using a comparative analysis that is, comparing the result of the initial condition with that after learning with the model being developed.

\section{RESULT AND DISCUSSION}

\section{Result}

The result of the research consists of the result of the preliminary study, the developmental process, the expert's validation, and the product try-out. Each stage will be described as follows. The first one is the result of the preliminary study, in this stage is to develop a creative learning model based on the project-based learning and the blended learning. Its activity is an interview with the related teachers at PGSD Study Program, identification of student's initial ability in planning and implementing a lesson, and a literature study on the elementary school learning. The interviews comprise the use of learning methods, the process of teaching-learning, and the student's responses after learning. The literature study consists of a study on the development of learning models for Mathematics in relation with pedagogical ability, contents, utilization of technology in learning, and theories of creative learning model development in reference to the project-based learning and the blended learning.

The result of the interviews with the teachers engaged in Mathematics learning at PGSD Study Program shows that 62,5\% (5 persons) of the Math teachers at PGSD remain to use an old, mechanistic way of teaching. This kind of teaching relies heavily on the teacher's explanation and exercises by students. It does not require students to be active, rather they tend to receive and become passive. Besides, an opportunity for students to become creative is minimal. Assignments and other activities remain giving a stress on completing class responsibility that leads to scoring.

Three Math teachers $(37,5 \%)$ at PGSD have tried to apply an innovative learning model, such as using a cooperative model, utilizing media in the form of power points, animation, and video. The cooperative learning model uses a face-to-face teaching that needs more contact time with the teachers. Consequently, when the teachers are absent their classes are empty, forcing them to make up classes. Time will become longer because of the addition of hours outside the scheduled class time. Of cource, this situation raises students' complaints because they have to allocate more time for make up classes that they do not have to. Learning with the use of powerpoints, animation and video has not been supported with the ability to select a suitable method, resulting in a one-way, ineffective teaching.

Out of eight Math teachers, two teachers (25\%) have made use of the ICT (e-learning), that is, the flexible learning and yet, it is not done maximally. The available learning materials are still dominated by texts and pictures only, moving printed learning materials into a digital form, and an innovative, online method of teaching is not yet practiced. Based on the data, Math learning which gives students an opportunity to creatively produce a product is still absent. Teaching-learning remains to focus on the completion of learning materials and fulfilling class assignments. The utilization of ICT as a means for students to explore things in depth is not yet done; it is only transfering printed materials into a digital form. The ability to integrate content mastery, pedagogical competence, and technological mastery and its application in learning is not yet optimal to make learning effective.

The result of interviews with students in the classrooms shows that the demand of classes remains in the completion of learning materials. Assignments to be done are intended only to fulfil their task and not as a creative work. Students only hope for scores and not for receiving new experiences, letting alone producing something. This is apparent that the assignments that have been completed are not their original work but copying other's work from the internet. They turned in their assignment because they hope to receive good scores instead of getting valuable experiences as prospective teachers.

The analysis of the interview results shows that there has not been a classroom instruction that motivates students' creativity in the subject Mathematics Learning at PGSD Study Program. Likewise, there has not been a good combination between content mastery, pedagogical ability, and technology utilization. The three abilities, when combined into one, will become a unity, which is so called TPACK (Technological Pedagogical and Content Knowledge). 
Richardson \& Mishra originally developed the concept of TPACK as a result of the fast technological advances in the society. In principle, the TPACK is the combination of technology, pedagogy, and content mastery which is adjusted to the context. According to Richardson \& Mishra (2017), a quality instructio needs a sense of complex understanding of the interrelated principal sources of knowledge: technology, pedagogy, and content, and how the three components are adjusted and applied into the existing context. This concept will expectedly give inspiration to teachers to design a creative learning for their students.

To motivate student's creativity, learning should be based on projects (i.e., project-based learning) to provide opportunity for students to produce by not only using and asking them to think to create a good product. In order for students to have time and opportunity to obtain a sufficient amount of information, they do not only need contact hours with the teacher, but they also need an online instruction design (blended learning). The concept of blending contact hours and online instruction gives students an opportunity to see beforehand, imitate, and add a value to produce a modified work or even a new piece of work. It was done so far because the PGSD students' creativity is still at the low level: seeing and remembering, imitating, and adding a value.

To produce a creative learning package, an exact development model is needed to provide with a manual on how to develop it. The result of the development model design was eventually decided by the ASSURE. The development design is done through the six stages, namely: 1) analyze learners, 2) state objectives, 3) select strategy, technology, media, and materials, 4) utilize media and materials, 5) require learner participation, 6) evaluate and revise (Smaldino, Russel, Heinich, \& Molenda, 2005).

The second one is, Process of Product Development, Expert's Test, and Result of Tryout. The process of product development follows the ASSURE development model in six stages of development as follows:

Analyze learners. The students who are selected as research subjects are the 2013 PGSD students, who have taken the subject Basic Concepts of Mathematics and Elementary School (ES) Teaching Mathematics 1. There are 3 classes as subjects to get information from, especially that related to the ability in making a lesson plan for ES Mathematics, the creativity in making learning activities, the creativity in preparing learning media, and the ability in using IT and utilizing internet for learning aid purposes. The results are shown in Table 1 below.

Table 1. Analyze Learners (Analysis of student characteristics) at Initial Condition

\begin{tabular}{clccccc}
\hline \multirow{2}{*}{ No } & \multirow{2}{*}{ Competence Category } & \multicolumn{4}{c}{ Frequency* } & \multirow{2}{*}{ Total } \\
\cline { 3 - 5 } & & VG & $\mathrm{G}$ & $\mathrm{P}$ & $\mathrm{VP}$ & \\
\cline { 3 - 6 } 1 & Ability in making lesson plans & 14 & 20 & 49 & 15 & 98 \\
2 & Creativity in designing learning activity & 10 & 15 & 40 & 33 & 98 \\
3 & Creativity in preparing supporting media & 9 & 17 & 30 & 42 & 98 \\
4 & Ability in using IT and internet & 40 & 48 & 10 & 0 & 98 \\
\hline *VG (Very Good), B (Good), P (Poor), VP (Very Poor) & & & & &
\end{tabular}

Table 1 above shows that there are still a lot of students $(65,3 \%)$ have poor ability in making a Lesson Plan. There are $74,5 \%$ of them are poor in designing learning activities, and $73,5 \%$ are still poor in preparing learning media. However, $89,8 \%$ of them are very good and good in their ability in using IT and the internet.

Based on the data, a clasical interview was then conducted in every classroom. It was found that such a generally poor condition is due to some causes. The first cause is the unclear information about how to make a lesson plan on the basis of the real condition of learners. The second cause is that the lesson plan that had been made only referred to the process standards and an example taken from the internet. The third cause is that the making of the lesson plan was only intended to fulfil a class requirement. 
The fourth cause is, there was less emphasis on creativity in designing innovative activities in the lesson plan. The fifth cause, there was no obligation in making media which support student's creativity. The sixth cause is, other resources which give more information and inspiration to do more were not used; all come from the teacher's materials and student's notes. Apart from all above, there was an interesting input from the students. They had not even seen their teachers teaching in a creative way as an example. The situation becomes a reason for the application of the teaching-learning concept taught by Ki Hajar Dewentara, namely, 3Ns
$($ Niteni $=$ Discern, Nirokke $=$ Imitate, Nambahi $=$ Add). This consept gives a thought that creativity will show up when students are given a chance.

State objectives. The result of the analysis on the students' ability, basic competency, and indicators as found in the subject Mathematics Learning was used to analyze learning objectives in line with the competencies to be achieved. The following describes the competencies in the subject Mathematics Learning 2.

Table 2. Basic Competencies and Description of Mathematics Learning 2

\begin{tabular}{|c|c|}
\hline Basic Competencies & Subject Description \\
\hline $\begin{array}{l}\text { Students are able to make } \\
\text { a lesson plan and put it } \\
\text { into practice those related } \\
\text { with materials on } \\
\text { geometri bangun datar, } \\
\text { bangun ruang, } \\
\text { transformational } \\
\text { geometry, presentation } \\
\text { and data analysis, and } \\
\text { finance mathematics } \\
\text { using innovative learning } \\
\text { models to increase the } \\
\text { quality of learning } \\
\text { mathematics and ES } \\
\text { education. }\end{array}$ & $\begin{array}{l}\text { This subject is offered in the 6th semester, weighting } 2 \text { credit hours. } \\
\text { It studies planning and learning implementation of geometri bangun } \\
\text { datar, bangun ruang, transformational geometry, presentation and } \\
\text { data analysis, and finance mathematics. } \\
\text { This subject is administered in the form of PROJECTS in making a } \\
\text { lesson plan to be implemented in a classroom in groups of } 2 \text { persons. } \\
\text { Every group should teach twice in one semester. Practice } 1 \text { should } \\
\text { last for } 35 \text { minutes and the Practice } 2 \text { is done at a primary school. The } \\
\text { teaching materials are adjusted to the available materials, its depth } \\
\text { depends on the allocated time. }\end{array}$ \\
\hline
\end{tabular}

Based on the competency statement, description of the subject, and the students' initial competency data, learning objective was then formulated for every meeting both in the contact hours and in online session. The following is the learning objectives for every meeting. 
Table 3. Objective Formulation of Mathematics Learning 2

\begin{tabular}{|c|c|}
\hline \multicolumn{2}{|r|}{ Objectives of Face-to-face Learning } \\
\hline Meetings & $\begin{array}{l}\text { Formulation of Learning Objectives } \\
\end{array}$ \\
\hline 1 & $\begin{array}{l}\text { a. Students are given an opportunity to listen and discuss together with the } \\
\text { teacher about the relationship between vision and mission of UKSW with the } \\
\text { process of preparation of prospective teachers, students are able to present } \\
\text { their formulation of commitment orally as a good prospective teacher based } \\
\text { on the vision and mission of UKSW. } \\
\text { b. Students are given an opportunity to listen and discuss together with the } \\
\text { teacher about the relationship between vision and mission of UKSW with the } \\
\text { process of preparation of prospective teachers, students show their } \\
\text { enthusiasm, perseverance, and appreciation without teacher's directives. }\end{array}$ \\
\hline 2 & $\begin{array}{l}\text { a. Students are given an opportunity to analyze the Lesson Plan which are } \\
\text { provided by the teacher, students in groups are able to give assessment of the } \\
\text { Lesson Plan students in groups are able to give assessment } \\
\text { b. Students are given an opportunity to assess the Lesson Plan already prepared } \\
\text { the teacher, students in groups are able to compare the Lesson Plan with that } \\
\text { belong to the group correctly and well. }\end{array}$ \\
\hline 3 & $\begin{array}{l}\text { a. Students are given an opportunity to observe a simulated lesson performed } \\
\text { by the teacher, students in groups are able to give assessment of the learning } \\
\text { process students in groups are able to give assessment } \\
\text { b. Students are given an opportunity to observe a simulated lesson performed } \\
\text { by the teacher, students with their own conscience show willingness to listen, } \\
\text { cooperate, and respect each other. }\end{array}$ \\
\hline 4 & $\begin{array}{l}\text { Students are given an opportunity to work in pairs, to be able to make a good } \\
\text { Lesson Plan for Mathematics teaching at an ES in accordance with the given } \\
\text { manual and materials and with the result of their independent study in the } \\
\text { online instruction. }\end{array}$ \\
\hline 5 & $\begin{array}{l}\text { Students are given an opportunity to present their Lesson Plan that they have } \\
\text { made, students are able to present their Lesson Plan fluently, in order, and with } \\
\text { self-confidence. }\end{array}$ \\
\hline 6 & $\begin{array}{l}\text { Students are given an opportunity to implement their finished Lesson Plan, } \\
\text { students are able to implement their Lesson Plan according to the order of } \\
\text { activities in the right order and correctly. }\end{array}$ \\
\hline & Formulation of the Online Learning Instruction \\
\hline $\begin{array}{l}\text { Online } \\
\text { Instruction }\end{array}$ & Formulation of Learning Objectives \\
\hline 1 & $\begin{array}{l}\text { Students are given an opportunity to watch a video about education in Finland, } \\
\text { Canada, and Germany, students are able to write a paper about a comparison of } \\
\text { education in the } 3 \text { countries with that in Indonesia and its application in } \\
\text { Mathematics lessons at the ES, adding some more information from the internet, } \\
\text { books, and other sources carefully and neatly. }\end{array}$ \\
\hline 2 & $\begin{array}{l}\text { Students are given an opportunity to watch a video about Qaryah Thayyibah } \\
\text { school and observe the school site, students are able to make reflection about the } \\
\text { school in relation with students' activities in the form of a video. }\end{array}$ \\
\hline 3 & $\begin{array}{l}\text { Students are given an opportunity to watch a video about the } 3 \text { Idiots. Students in } \\
\text { groups are able to make a report on the film review which is related to the } \\
\text { concept of learning, teaching, respect the students, creativity, and the meaning } \\
\text { of learning for a person in the form of power points and is copied on a CD or } \\
\text { DVD. }\end{array}$ \\
\hline
\end{tabular}


Select method, media, and materials. The third step in this development method is deciding methods, media, and teaching materials that will be used both in the face-to-face and online instructions. The result was divided into two available categories of methods, media, and teaching materials each for face-to-face and online instructions. For the face-to-face instruction, the method used is discussion and group work, and group investigation using power point media, which contain motivation and activities that must be done to complete a project. The online instruction takes the form of group investigation aided with activities and manual available in the online mode, namely, the F-learning (flearn.uksw.edu).

Utilize media and materials. The plan that has been made in Step 3 was the followed by a lesson plan for both the face-to-face and the online instructions. The tools needed are the Lesson Plan, Student Worksheets, Media (power points, ideo, audio, pictures, and online materials). These tools were assessed first by experts in media, instructions and materials before use. Detail assessment from expert's judgment is shown in Table 4 below.

Table 4. Result of Expert's Judgment

\begin{tabular}{clcc}
\hline No & \multicolumn{1}{c}{ Indicators } & Average & Category \\
\hline 1 & Lesson Plan & 4,25 & Very good \\
2 & Learning Media & 3,67 & Good \\
3 & Testing Instruments & 3,96 & Good \\
4 & Online Learning Activities & 3,84 & Good \\
5 & Learning materials & 3,73 & Good \\
\hline
\end{tabular}

Require learner participation. The next step was engaging students in the instructions. The students must be involved actively in the instructions to make them effective and objectives achieved. Because the design used was the blended learning, the students were required to be independent. The learning process was conducted according to the plan both in the face-to-face and the online instructions totalling 14 meetings, 1 meeting for pure face-to-face instruction and others were conducted in a blended learning mode (face-to-face and online).

Evaluated and revise. Based on the result of the expert's assessment and learning implementation, there were some online facilities that should be improved. In the introductory part of the instruction, it was expected that there must be videos, not only texts, about the demand of the $21^{\text {st }}$ century learning situations as well as competency expectations in the subjects to be taken by the students. There must also be a detailed manual for every online activity to avoid many questions that arose while students were learning independently. It also needs videos about learning Mathematics taken from real online implementations, so that students are inspired and able to produce creative learning plans. The following is the result of the expert's assessment and revisions after the implementation in ghe classroom.

Result of Model Try-out. To see the effectiveness of the model, a try-out was conducted at Grade 1 following the order that has been determined beforehand. The instruction was a project-based one to produce a creative lesson plan which would be used for teaching at schools by the students. The lesson plans were then assessed by the available criteria and compared with the scores obtained before the students received the learning. The design used was the one group pretest-posttest design and he results were analyzed by Paired-Samples T Test. 


\begin{tabular}{lccccc}
\hline & N & Minimum & Maximum & Mean & Std. Deviation \\
\hline Pretest & 33 & 60.00 & 85.00 & 83.06 & 7.93 \\
Posttest & 33 & 70.00 & 90.00 & 66.45 & 7.15 \\
Valid N (listwise) & 33 & & & & \\
\hline
\end{tabular}

Tabel 6. Results Paried-Samples T Test

\begin{tabular}{|c|c|c|c|c|c|c|c|c|c|}
\hline \multirow[b]{4}{*}{ Pair 1} & \multirow[b]{4}{*}{$\begin{array}{l}\text { Pretest - } \\
\text { Posttest }\end{array}$} & \multicolumn{5}{|c|}{ Paired Differences } & \multirow{3}{*}{$\mathrm{t}$} & \multirow{3}{*}{ df } & \multirow{3}{*}{$\begin{array}{l}\text { Sig. (2- } \\
\text { tailed) }\end{array}$} \\
\hline & & \multirow[t]{2}{*}{ Mean } & \multirow[t]{2}{*}{$\begin{array}{c}\text { Std. } \\
\text { Deviation }\end{array}$} & \multirow[t]{2}{*}{$\begin{array}{l}\text { Std. } \\
\text { Error } \\
\text { Mean }\end{array}$} & \multicolumn{2}{|c|}{$\begin{array}{c}95 \% \text { Confidence } \\
\text { Interval of the } \\
\text { Difference }\end{array}$} & & & \\
\hline & & & & & Lower & Upper & & & \\
\hline & & -16.606 & 10.186 & 1,773 & -20.212 & $-12,994$ & -9.366 & 32 &, 000 \\
\hline
\end{tabular}

The data in Tables above show that the average pretest score is 66,45 and the posttest score is 83,06 with sig.(2-tailed) 0,000 which mean that there is a difference between before and after implementation of the project-based blended learning models.

\section{Discussion}

Based on the results of the interviews show that the learning that has been done by the teacher is still varied. Five of the eight teachers are still using mechanistic teaching models. This traditional teaching pattern is more emphasis on face-to-face and the use of text and image media just have a problem if the lectures can not be done for one reason or another. Though teacher teaching style can influence student learning reflection (Hsieh, 2011). These conditions require more creative learning innovations.

In the other hand, the condition of the students in making learning planning, creativity of designing activities and the use of media is still low. This situation is certainly not the expected condition. A good teacher and prospective teacher should be creative so that it can be an example for students to be creative (Morais \& Azevedo, 2011). Likewise creativity is one of the best teacher thinking habits (Henriksen, 2016). Fortunately, the students in this study have advantages in mastering ICT and internet that can be their capital to develop more creative learning. This is one of the reasons for the need to develop a project-based blended learning model.

In this research, successfully learning designs have implemented face-to-face learning and online learning. Lesson plan development projects, discussions, making learning media, and online learning activities show that this blended learning learning has stimulated student interaction, facilitated student learning process, and fostering an affective learning climate (Boelens et al., 2017).

Student creativity in making lesson plan in this research is supported because of the learning environment that foster creativity from the student (Soh, 2017, Richardson \& Mishra, 2017). Examples of lesson plan, videos, and movies are the learning environments provided by teachers. A positive learning environment (Tsai \& Chung, 2015) is what keeps students motivated and creative according to what Tsai \& Chung has gained.

The increase of score from pre test to post test is significant difference strengthening the result of other research that learning projectbased learning can improve student learning success, learning outcome (Ergul \& Kargin, 2014; Zaouganeli et.al., 2014; Han, Capraro \& Capraro, 2016) .

\section{CONCLUSION AND SUGGESTION}

Based on the analysis, findings and the discussion, it can be concluded that the creative learning model using the project-based learning and the blended learning can be developed by the ASSURE model. The research was conducted in 6 stages, namely, 1) analyze learners, 2) state objectives, 3) select strategy, technology, media, and materials, 4) utilize media and materials, 5) require learner participation, 6) evaluate and revise. The result of implementing the model is valid as viewed from instructional aspect (lesson plans, learning media, and instrument assessment), online learning activities, and learning materials. This model is also effectively usable in instructions to 
produce creative lesson plans for teaching Elementar School Mathematics as it is shown by the difference in the average pretest and posttest scores with sig. (2-tailed) 0,000.

Based on the results of research and analysis has been conducted on the research results, the suggestions of the results of this study are lecturers are suggested to give their students a great opportunity to develop their creativity. Students' creativity grows in line with the opportunity given in every learning prepared and done by the lecturers. Learning is done by online system instead of a common face to face. Online system enables students to explore learning materials given and develop them to support their project. They will produce good qualified project by project-based learning

\section{REFERENCES}

Boelens, R., Wever B.D. \& Voet, M. 2017. Four key challenges to the design of blended learning: A systematic literature review. Educational Research Review, Vol.22. November 2017, 1-18

Charles D. Dziuban. 2004. Blended Learning. Central Florida: EDUCAUSE Center for Applied Research Volume 2004, Issue 7.

Ergul, N.R., Kargin, E.K. 2014. The Effect of Project-based Learning on Students' Science Success. Procedia - Social and Behavioral Sciences, 136, 537-541.

Giacomini, L. 2015. Using "Storybird" in Young Learners' Creative Writing Class. Teaching Technique: English Teaching Forum, 35-37.

Han, S., Capraro, R., Capraro, M. 2016. How science, technology, engineering, and mathematics project-based learning affects high-need students in the US. Learning and Individual Differences, 51, 157-166.

HASYIM, Nurhikmah; HALING, Abdul. The eLearning Needs Analysis in Graduate Programs of Universitas Negeri Makassar. Journal of Educational Science and Technology (EST), [S.1.], p. 233-242, dec. 2017. ISSN 2477-3840. Available at: <http://ojs.unm.ac.id/JEST/article/view/4
748>. Date accessed: 21 Jul. 2018.

doi:http://dx.doi.org/10.26858/est.v3i3.47 48.

Henriksen, Danah. 2016. The seven transdisciplinary habits of minds of creative teachers: An exploratory studi of award winning teachers. Teaching Skills and Creativity, Vol 22 December 2016, Pages 212-232. https://doi.org/10.1016/j.tsc.2016.10.007

Hsieh, S.W., et.al. 2011. Effects of teaching and learning styles on students' reflection levels for ubiquitous learning. Computers \& Education, Volume 57, Issue 1, August 2011, Pages 1194-1201. https://doi.org/10.1016/j.compedu.2011.0 1.004

Jared A. Carman, 2005. Blended Learning Design: Five Key Ingredients. Diambil dari

http://www.agilantlearning.com/pdf/Blen ded Learning Design.pdf diunduh, 25 Oktober 2012.

Joyce, B dan Marsha, W. 2015. Models of Teching. USA: Allyn: A. Person Education Company

Khairullina, N.e. a. 2016. Development of Creative Activity os Students in the System of the Organizational Culture of the Modern University. International Journal of Enviromental \& Science Education, $11 \quad$ No.4, 2171-2184. doi:10.12973/ijese.2016.588a

Koparan \& Guven. 2014. The Effec of Projectbased Learning on the Statistical Literacy Levels of Students 8th Grade. European Journal of Educational Research, 3 No. 3, 145-157. Retrieved from http://www.eurojedu.com

Krinistsyna, Anastasiya Vyacheslavovna, e. a. 2016. Characteristics of the Creative Development technologies Applying During the Work with Students. International Journal of Enviromental \& Science Education, 11 NO. 18, 1170911720.

Lamima \& Dangwal. 2017. Blended Learning: An Innovative Approach. Universal 
Journal of Educational Researh, 5 no. 1, 129-136. doi:10.13189/ujer.2017.050116

Liu, P. 2016. Technology Integration in Elementary Classrooms: Teaching Practices of Student Teachers. Australian Journal of Teacher Education, 41(3), 87104.

Morais, Maria Fatima \& Azevedo, Ivete. 2011. What is a Creative Tecaher and What is a Creative Pupil? Perceptions of Teachers. Procedia Social and Behavioral Sciences, Vol 12, 2011, Page 330-339, https://doi.org/10.1016/j.sbspro.2011.02.0 $\underline{42}$

Powel, A., et.al. 2015. Blending Learning: The Evolution of Online and Face-toFace Education from 2008-2015. iNACOL, 120.

Richardson, C \& Mishra, P. 2017. Learning environments that support student creativity: Developing the SCALE. Thinking Skills and Creativity, 27, 45-54.

Smaldino, S.E,Russel, J.D. Heinich, R. \& Molenda, M. 2005. Intructional Technology and Media for Learning . New Jersey : Pearson Merril Prentice Hall Inc

Soh, K. 2017. Fostering student creativity through teacher behaviors. Thinking Skills and Creativity, 23, 58-66.
Tsai, C.Y., Horng, JS, Liu, CH, Hu, DC, Chung YC. 2015. Awakening student creativity: Empirical evidence in a learning environment context. Journal of Hospitality, Leisure, Sport \& Tourism Education, 17, 28-38.

Vastenhouw, M., 1982. Metode Pengajaran Proyek. s.1.:Keluarga Mahasiswa BAPEMSI

Widiana, I Wayan, I. N. 2016. Improving Students' Creative Thinking and Achievement through the Implementation of Multiple Intelligence Approach with Mind Mapping. International Journal of Evaluation and Research in Education, 5 No. 3, 246-254.

Winataputra, U. S. 2001. Model-model Pembelajaran Inovatif. Jakarta : Pusat Antar Universitas untuk Peningkatan dan Pengembangan Aktivitas Instruksional, Dirjen Dikti

Wallas, G. 1926. The art of thought. London: Jonathan Cape.

Zaouganeli, E., Tysso, V., Feng, B., Arneses, K., Kapetanovic, N. 2014. Projrct-based learning in programming classes - the effect of open projrct scope on student motivation and learning outcome. IFAC Proceedings Volumes, 47, 12232-12236. 